\title{
A Policy Brief on Vocational and Technical Education in Turkey
}

\author{
${ }^{1}$ Hilal Ayan Karabatman
}

\begin{abstract}
The importance of vocational and technical education (VTE) is increasing in response to the rapidly changing information, technology, production methods, and developments in every aspect of life. The only way to survive in this age and to compete with this challenge is to continuously develop comprehensive educational policies that relate to each other (MoNE, 2018). In this sense, VTE has a very central role in providing societies with the knowledge and skills that the 21 st century requires (Çınar, Döngel, \& Söğütlü, 2009). For this reason, in educational policy discussions, an area that requires as much attention as other areas of education is VTE. This paper aims to review the current problematic states of VTE in Turkey and make recommendations for improving it.
\end{abstract}

Keywords: Vocational education, technical education, education policy

\section{Türkiye'de Mesleki ve Teknik Eğitime İlişkin Bir Politika Notu}

\section{ÖZET}

Hızla değişen bilgi, teknoloji, üretim yöntemleri ve hayatın her alanında yaşanan gelişmeler karşısında mesleki ve teknik eğitimin (MTE) önemi artmaktadır. Bu çağda ayakta kalabilmenin ve bu zorlukla rekabet edebilmenin tek yolu, sürekli olarak birbiriyle ilişkili kapsamlı eğitim politikaları geliştirmektir (MEB, 2018). Bu anlamda MTE, 21. yüzyılın gerektirdiği bilgi ve becerilerin toplumlara kazandırılmasında çok merkezi bir role sahiptir (Çınar, Döngel ve Söğütlü, 2009). Bu nedenle eğitim politikası tartışmalarında diğer eğitim alanları kadar dikkat edilmesi gereken bir alan da MTE'dir. Bu makale, Türkiye'de MTE'nin mevcut sorunlu durumlarını gözden geçirmeyi ve iyileştirmeye yönelik önerilerde bulunmayı amaçlamaktadır.

Anahtar kelimeler: Mesleki eğitim, teknik eğitim, eğitim politikası

\section{INTRODUCTION}

The importance of vocational and technical education (VTE) is increasing in response to the rapidly changing information, technology, production methods, and developments in every aspect of life. All these developments and changes raise the need for continuous and systematic plans in occupational aspects and the workforce (Arkan, 2019; Gelişli, Beisenbayeva, Sultanbek, \& Ussenova, 2016; OECD, 2010; MoNE, 2018). Moreover, the distinction between countries according to income level has now turned into a distinction according to educational qualifications. The only way to survive in this age and to compete with this challenge is to continuously develop comprehensive educational policies that relate to each other (MoNE, 2018). In this sense, VTE has a very central role in providing societies with the knowledge and skills that the 21 st century requires (Çınar, Döngel, \& Sögütlü, 2009). For this reason, in educational policy discussions, an area that requires as much attention as other areas of education is VTE. This paper aims to review the current problematic states of VTE in Turkey and make recommendations for improving it.

\section{THE SIGNIFICANCE OF VOCATIONAL AND TECHNICAL EDUCATION POLICY}

VTE aims to ensure that individuals are systematically supported with the occupational knowledge, skills, and competencies that they will need in different areas of social life (Gelişli,

\footnotetext{
${ }^{1}$ Corresponding author: Address: Faculty of Education, Department of Educational Sciences, Boğaziçi University, Istanbul, TURKEY, hilal.ayan@boun.edu.tr, Phone: +902123596833
} 
Beisenbayeva, Sultanbek, \& Ussenova, 2016; OECD, 2010). Therefore, the making and implementation of sustainable, evidence-based, and strong education policies related to vocational and technical education are gaining importance day by day.

In response to this situation, recently, countries all over the world are going through major revisions in their VTE systems (Bagale, 2015; Özer, 2020). The most recent and major step of Turkey in this process has started with the announcement of the 2023 Education Vision by the Ministry of National Education in 2018 (Özer, 2019, 2020). With this step, the ministry aimed at a comprehensive transformation in VTE to respond to the emerging new world order (Özer \& Suna, 2019).

Despite all the importance attributed, VTE has been overshadowed by other fields of education in political debates (OECD, 2010). Yet, it is necessary and significant to review this step to contribute to the future of VTE in Turkey with an educational policy orientation. Acknowledging the importance of VTE and of including issues related to VTE in educational policy discussions, this policy brief, will review VTE in Turkey within the scope of the 2023 Education Vision policy document. Problem areas related to VTE will be proposed. Then, recommendations will be made for improving the VTE policy in Turkey.

\section{VOCATIONAL AND TECHNICAL EDUCATION IN 2023 EDUCATION VISION}

The 2023 Education Vision announced to the public in October 2018 offers a new roadmap for VTE (Özer, 2018, 2019, 2020). The new roadmap determined by the 2023 Education Vision claims to build a dynamic vocational education that is sensitive to the sector and constantly updates itself according to the priorities of the country (Özer, 2018; MEB, 2018a). Under this claim, it is aimed to strengthen the relationship between education, production, and employment in vocational education. Within the framework of the new roadmap developed in line with the 2023 Education Vision, there are seven main targets related to VTE. These are: 1) increasing the value attributed to vocational and technical education; 2) increasing guidance and access opportunities in vocational and technical education; 3) developing a new generation of the curriculum; 4) developing educational environments and human resources; 5) training professional personnel needed by business people investing abroad; 6) strengthening education-employment-production relationship and 7) raising the qualified labor force needed by the domestic and national defense industry (MoNE, 2018).

Solid steps have been taken concerning these targets. Improvements at various levels have begun to be implemented. The ministry has started to get positive reactions from the education authorities and the sector. The developments realized in line with the targets taken have been evaluated by civil organizations (Özer, 2018; Özer \& Suna, 2019). The policy actions are evaluated, and the improvements are followed through the educational policy analysis reports published by ERG, TEDMEM, and SETAV. Nevertheless, problems in VTE continue to exist, and challenges remain with us (Arkan, 2019; Diker Coşkun, 2020; OECD; 2019, 2020; Özer, 2019). Therefore, identifying these problems is essential for improving the current situation of VTE and for reaching solutions in the long run.

\section{PROBLEMATIC ASPECTS AND RELATED RECOMMENDATIONS FOR IMPROVING POLICY}

When the targets are compared with the achievements mentioned in these reports and with the current situation, problematic aspects of VTE become evident. The problems in VTE are generally affected by the problems in the education system of the country in general and are reflected in the field as an extension of them (OECD, 2019, 2020; Özer, 2019, 2020, 2021). Problems are often centered around the issues of quality of VTE education, access to VTE, and gaps in the policy implementation process (Arkan, 2018, 2019; OECD, 2020; Özer, 2019; TEDMEM, 2021). There are also improvable areas within the VTE itself (OECD, 2019, 2020; MoNE, 2018). Below, these problems and areas for improvement will be summarized and recommendations will be made for each. 
- The overall structure of the education system in Turkey can be prominently problematized as a fact that slows down the development of VTE. The highly centralized structure of the education system and top-down education policies stand as a reality that shapes VTE and hinders the potential of different stakeholders, industries, different sectors, and at most the educators and the students.

- Informal and uninsured working and employment and job insecurity are still problems of the workplace. There are violations of many fundamental rights in the field including VTE institutions. Therefore, policies related to VTE should seriously involve measurements against informal and uninsured employment. Thus, a more decentralized, flexible, and inclusive system can be obtained.

- The needed adaptation to the rapidly changing technology has still not been completed and the old methods and tools are still used in VTE. For this reason, policies should shape the financial and institutional initiatives necessary for rapid technological changes in VTE that will respond to technology and infrastructure problems.

- In the scope of the relationship between the European Union and Turkey, the necessary standards and agreements for unification are still not completed. VTE is still affected by politically controversial aspects of this relationship. In addition, there are points where the steps taken only to comply with the standards are contextually far from our country's own needs and problems. Therefore, the development of appropriate policies should be far from political debate, aimed at meeting standards, but at the same time not out of context. In this sense, my recommendation is fundamental and that requires big change and transformation: the stakeholders and the authorities in the field of education and workplace should be fully involved both in the making and implementation of VTE policies.

- Quality measurement and assessment in VTE are lacking. In relevant policies, measurement, evaluation, and supervision should be at least as prominent as other factors. Consultancy services and supervision should be provided to both VTE schools, employers, and companies.

- Skill mismatch remains one of the most crucial problems that require long-term policies. When the strong bond between education and the labor market is ignored, policies to eliminate skill mismatch focus only on VET, existing problems in the labor market are not seen, as a result, the problems cannot be solved and on the contrary, the problems become stable. In addition, VET graduates are mostly employed outside the field, so horizontal skill mismatches occur. On the other hand, there is a surplus of skills in the labor market. Overall, regarding the demands of the job market, it is recommended that the location and education capacity of VTE schools and institutions be restructured according to the supply-demand balance.

- Problems with long-term (un)employability are another aspect that needs to be politically addressed. This problem is related to the content and quality of VTE education. The knowledge and skills of VTE graduates may become dysfunctional or insufficient in the long run due to the fast changes in the occupations. On the contrary, long-term, and permanent employment opportunities for general education graduates due to the knowledge, skills transmitted to them should also be created for VTE graduates. This also hinders flexibility between jobs. Thus, policies should focus on designing lifelong employment patterns within VTE by strengthening academic knowledge and general skills that can encourage flexibility and that also supported by a lifelong and life-wide perspective.

\section{SUMMARY AND CONCLUSIONS}

In this paper, first, it was explained how important is the of VTE in the rapidly changing and developing world. In parallel, it is emphasized that only strong VTE policies can respond to the 
changing conditions in the occupational context and requirements of work-life. Thus, while all countries have started focusing on VTE at the political level, Turkey also included VTE extensively in its 2023 Education Vision announced in 2018. Along with the disclosure of the objectives in the aforementioned policy document, various education policy analysis reports have been published, addressing the current situation and achievements including that of VTE. When the roadmaps announced by the ministry and these reports are reviewed and examined carefully, it will be useful to make policy recommendations for the future of VTE in Turkey. In sum, this paper aimed to create a policy brief prepared for making present policy recommendations for VTE in Turkey.

Despite the steps taken, VTE education has both structural, systemic, and content-related problems in both qualitative and quantitative manners. Hence, it is very necessary and important to make and implementing such policies that are based on the principle of lifelong learning, that are inclusive, that attach importance to cooperation, evaluation, and supervision, that have long-term and concrete goals, that focus on flexibility and the principle of learning/ teaching to learn, and most importantly, are scientific and research-based, will ensure the development of our country in every sense.

\section{REFERENCES}

[1] Arkan, A. (2018). Mesleki Eğitimin Geleceği. İstanbul: SETAV. Retrieved from https://www.setav.org/mesleki-egitimin-gelecegi/

[2] Arkan, A. (2019). Eğitim Zirvesi ve Meslek Eğitimi I. İstanbul: SETAV. Retrieved from https://www.setav.org/egitim-zirvesi-ve-meslek-egitimi-i/

[3] Bagale, S. (2015). Technical education and vocational training for sustainable development. Journal of Training and Development, 1(1), 15-20.

[4] Çınar, H., Döngel, N., \& Sögütlü, C. (2009). A case study of technical and vocational education in Turkey. Procedia Social and Behavioral Sciences, 1, 160-167.

[5] Diker Coşkun, Y. (2020). Eğitim izleme raporu 2020: Eğitimin içeriği. Eğitim Reformu Girişimi. Retrieved from https://www.egitimreformugirisimi.org/egitim-izleme-raporu-2020-egitimin-icerigi/

[6] ETF (2018). Governance Arrangements for Vocational Education and Training in ETF Partner Countries: Analytical Overview 2012-2017. Turin: ETF. https://www.etf.europa.eu/sites/default/files/201902/VET\%20governance\%20in\%20ETF\%20partner\%20countries\%202012-17.pdf.

[7] Gelişli, Y., Beisenbayeva, L., Sultanbek, M. Z., \& Ussenova, A. (2016). Vocational Education Systems in Turkey and The World: New Trends and Problems. International Journal on New Trends in Education and Their Implications, 7(3), 1-10.

[8] Jeon, S. (2021). Four ways to strengthen teaching and leadership in vocational education and training. OECD Education and Skills Today. OECD Publishing. https://oecdedutoday.com/four-ways-strengthenteaching-leadership-vocational-education-training-vet/

[9] Millî Eğitim Bakanlığı (MEB). (2018). Türkiye'de mesleki ve teknik eğitimin görünümü. Eğitim Analiz ve Değerlendirme Raporları Serisi No: 1. Ankara: MEB.

[10] MoNE (2018). External quality assurance report for VET institutions, Education. Analysis and Evaluation $\quad$ Series, No. $2 . \quad$ Ankara: http://mtegm.meb.gov.tr/meb_iys_dosyalar/2018_11/29122622_mesleki_ve_teknik_ ortaogretimde_kurumsal_dis_degerlendirme_raporu_web_29kasim_1.pdf.

[11] MoNE (2018). Turkey's Education Vision 2023: Ankara: MoNE. https://2023vizyonu.meb.gov.tr/doc/2023_VIZYON_ENG.pdf.

[12] OECD (2010). Learning for Jobs. Synthesis Report of the OECD Reviews of Vocational Education and Training. Paris: OECD Publishing. Retrieved from https://www.oecd.org/education/skills-beyondschool/Learning\%20for\%20Jobs\%20book.pdf

[13] OECD (2015). OECD reviews of vocational education and training: Key massages and country summaries. Paris: OECD Publishing. Retrieved from https://www.oecd.org/education/skills-beyondschool/OECD_VET_Key_Messages_and_Country_Summaries_2015.pdf

[14] OECD (2019). Education at a Glance 2019, Turkey. NICEV. Retrieved from http://www.nicev.org.tr/Education\%20At\%20A\%20Glance\%202019.pdf

[15] OECD (2020). Education Policy Outlook: Turkey. OECD Publishing. Available at: www.oecd.org/education/policy-outlook/country-profile-Turkey-2020.pdf. 
[16] Özer, M. (2019). Background of problems in vocational education and training and its road map to solution in Turkey's education vision 2023. Yükseköğretim ve Bilim Dergisi, 9(1), 1-11.

[17] Özer, M. (2019). Reconsidering the fundamental problems of vocational education and training in Turkey and proposed solutions for restructuring. İstanbul Üniversitesi Sosyoloji Dergisi, 39(2), 455-473. https://doi.org/10.26650/SJ.2019.39.2.0098

[18] Özer, M., \& Suna, H. E. (2019). Future of vocational and technical education in Turkey: Solid steps taken after Education Vision 2023. Journal of Education and Humanities, 10(20), 165-192.

[19] Özer, M. (2020). The Contribution of the Strengthened Capacity of Vocational Education and Training System in Turkey to the Fight against Covid-19. Yükseköğretim Dergisi, 10(2), 134-140.

[20] Özer, M. (2020). Türkiye'de mesleki eğitimde paradigma değişimi. Gazi Eğitim Fakültesi Dergisi, 40(2), 357-384.

[21] Özer, M. (2021). A new step towards narrowing the achievement gap in Turkey: "1,000 schools in vocational education and training" project. Bartın University Journal of Faculty of Education, 10(1), 97-108. https://doi.org/10.1016/buefad.824697

[22] Milli Eğitim Bakanlığı (MEB) (2018). 2023 Eğitim Vizyonu. Ankara: T.C. Milli Eğitim Bakanlığı, www.meb.gov.tr.

[23] Ministry of National Education (MoNE) (2018). Outlook of Vocational and Technical Education in Turkey. Ankara: Turkish Ministry of National Education, www.meb.gov.tr.

[24] TEDMEM (2021). 2020 eğitim değerlendirme raporu. Değerlendirme Dizisi 7. Ankara: Türk Eğitim Derneği. Retrieved from https://tedmem.org/download/2020-egitim-degerlendirmeraporu? wpdmdl=3644\&refresh=60e59c7110bf21625660529 